\title{
Research Article \\ Release of a Wound-Healing Agent from PLGA Microspheres in a Thermosensitive Gel
}

\author{
H. A. Machado, ${ }^{1}$ J. J. Abercrombie, ${ }^{1}$ T. You, ${ }^{1}$ P. P. DeLuca, ${ }^{2}$ and K. P. Leung ${ }^{1}$ \\ ${ }^{1}$ US Army Dental and Trauma Research Detachment, Institute of Surgical Research, 3650 Chambers Pass, Building 3610, \\ JBSA Fort Sam Houston, TX 78234-6315, USA \\ ${ }^{2}$ Faculty of Pharmaceutical Sciences, University of Kentucky College of Pharmacy, Lexington, KY 40506, USA
}

Correspondence should be addressed to K. P. Leung; kai.p.leung.civ@mail.mil

Received 13 May 2013; Revised 15 August 2013; Accepted 16 August 2013

Academic Editor: Frederic Lagarce

Copyright (C) 2013 H. A. Machado et al. This is an open access article distributed under the Creative Commons Attribution License, which permits unrestricted use, distribution, and reproduction in any medium, provided the original work is properly cited.

\begin{abstract}
The purpose of this research was to develop a topical microsphere delivery system in a thermosensitive $20 \%$ poloxamer 407 gel (Pluronic F127) to control release of KSL-W, a cationic antimicrobial decapeptide, for a period of 4-7 days for potential application in combat related injuries. KSL-W loaded microsphere formulations were prepared by a solvent extraction-evaporation method (water-oil-water), with poly (D,L-lactic-co-glycolic acid) (PLGA) (50:50, low-weight, and hydrophilic end) as the polymeric system. After optimization of the process, three formulations (A, B, and C) were prepared with different organic to water ratio of the primary emulsion while maintaining other components and manufacturing parameters constant. Formulations were characterized for surface morphology, porous nature, drug loading, in vitro drug release, and antimicrobial activity. Microspheres containing $20 \%$ peptide with porous surfaces and internal structure were prepared in satisfactory yields and in sizes varying from 25 to $50 \mu \mathrm{m}$. Gels of $20 \%$ Pluronic F127, which were liquid at or below $24.6^{\circ} \mathrm{C}$ and formed transparent films at body temperature, were used as carriers for the microspheres. Rheological studies showed a gelation temperature of $24.6^{\circ} \mathrm{C}$ for the $20 \%$ Pluronic F127 gel alone. Gelation temperature and viscosity of formulations $\mathrm{A}, \mathrm{B}$, and $\mathrm{C}$ as a function of temperature were very close to those of the carrier. A Franz diffusion cell system was used to study the release of peptide from the microspheres suspended in both, phosphate-buffered saline (PBS) and a 20\% Pluronic F127 gel. In vitro release of greater than 50\% peptide was found in all formulations in both PBS and the gel, and in one formulation there was a release of $75 \%$ in both PBS and the gel. Fractions collected from the release process were also tested for bactericidal activity against Staphylococcus epidermidis using the broth microdilution method and found to provide effective antimicrobial activity to warrant consideration and testing in animal wound models for treating combat-related injuries.
\end{abstract}

\section{Introduction}

Combat-related injuries during military operations have been associated with infectious complications due to the nature of wounding, giving rise to significant devitalized tissue, contamination of battlefield wounding agents with various bacteria, and the emergence of multidrug-resistant nosocomial pathogens, especially gram-negative bacteria. Investigations are underway to identify the source of these bacteria and to try to mitigate their associated morbidity and mortality. As in the US civilian medical community, new antimicrobial agents are needed to treat these infections. Platforms to identify infection and its antimicrobial resistance profile also are needed to ensure that appropriately focused therapy is instituted [1].

Cationic antimicrobial peptides are excellent candidates for development as novel therapeutic agents to complement conventional antibiotic therapy [2]. In contrast to conventional antibiotics, antimicrobial peptides have lower propensity to induce antibiotic resistance. These peptides generally exhibit a broad range of bactericidal activity which requires a short contact time to induce killing. However, many available peptide and protein drugs are characterized by short biological half-lives. They are easily degraded by enzymes and pass poorly through biological barriers because of deficient diffusivity and low partition coefficient [3-6]. 
The assessment of protein stability in delivery systems is increasingly being integrated into research programs. Among the various means used, nanospheres or microspheres made of poly (D,L-lactic-co-glycolic acid) (PLGA) have gained popularity, mainly because of their tissue compatibility and biodegradability [7]. Poly (lactic-co-glycolic acid) (PLGA) is made from two monomers, lactic acid and glycolic acid. The ratio of the monomers and the molecular weight set the identity and properties. PLGA is both biodegradable and biocompatible, and since both monomers occur naturally it has minimal toxicity. PLGA is naturally amorphous (not crystalline). While poly (lactic) and poly (glycolic) acid are poorly soluble in most solvents; PLGA dissolves in many common solvents including tetrahydrofuran, acetone, ethyl acetate, and chlorinated solvents. The Food and Drug Administration (FDA) has approved PLGA for preparation of micro- and nanoparticles.

Peptide encapsulation and preparation of PLGA microspheres are generally performed using a water-in-oil-inwater double-emulsion technique. In this process, the active ingredient is first dissolved in an aqueous phase (W), which is then emulsified in an organic solvent $(\mathrm{O})$ of a polymer to make a primary $\mathrm{W} / \mathrm{O}$ emulsion. This primary emulsion is further mixed in an emulsifier-containing aqueous solution (W) to make a $\mathrm{W} / \mathrm{O} / \mathrm{W}$ double emulsion. The removal of the polymer solvent leaves microspheres in the aqueous continuous phase, making it possible to collect them by filtering or centrifuging [8-10]. Incorporating the drug-loaded microspheres into a thermoreversible gel would provide a novel platform in the treatment of persistent infections arising from localized biofilms [11-13].

Microspheres with high peptide incorporation efficiency can be prepared from low molecular weight and hydrophilic acid ended PLGA polymers [14]. As a vehicle or carrier, Pluronic F-127, in concentrated solutions ( $>18 \%$ in water), can be transformed from low-viscosity transparent solutions to solid gels on warming to body temperature $[15,16]$. This phenomenon, therefore, suggests that when poured or sprayed onto the skin, the gel preparation will form a semisolid artificial barrier and a sustained release depot.

Pluronic F-127 consist of ethylene oxide (EO) and propylene oxide $(\mathrm{PO})$ blocks arranged in a triblock structure $(\mathrm{EO})_{x}-(\mathrm{PO})_{y}-(\mathrm{EO})_{x}$; the chemical formula is $\mathrm{HO}[\mathrm{CH}-$ $\left.\mathrm{CH}_{2} \mathrm{O}\right]_{x}\left[\mathrm{CH}\left(\mathrm{CH}_{3} \mathrm{CH}_{2} \mathrm{O}\right)\right]_{y}$ where $x=95-105$ and $y=54-$ 60 . It has a molecular weight of about 12,600 $(9,840-14,600)$. The gelation mechanism of pluronic solutions indicates a micellar mode of association. Micelle formation occurs at the critical micellization temperature as a result of polypropylene oxide block dehydration. With the increasing of temperature, micellization becomes more important and, at a certain temperature, micelles come into contact and no longer move. This packing of micelles and micelle entanglement might be the possible mechanism of pluronic solution gelation with increase of temperature.

The purpose of the present work was to develop a thermosensitive gel loaded with biodegradable microspheres that release an antimicrobial peptide up to one week. The microspheres were manufactured using a water-in-oilin-water double-emulsion solvent evaporation technique.

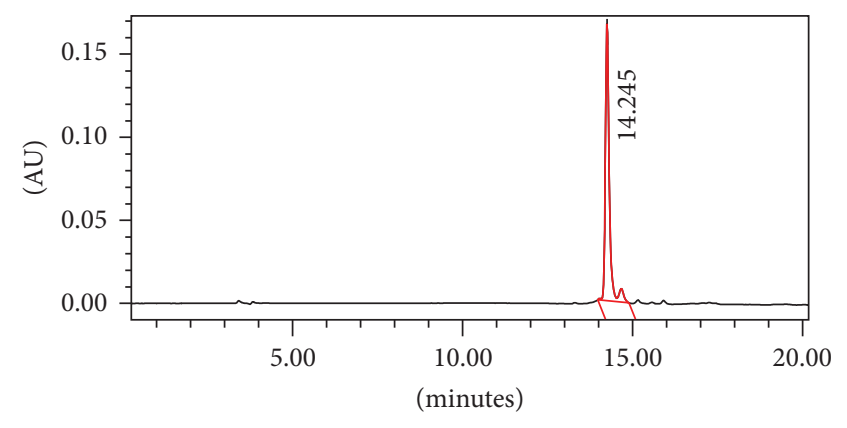

FIGURE 1: High-performance liquid chromatogram of KSL-W $(0.5 \mathrm{mg} / \mathrm{mL})$ in DI water.

By monitoring the organic to water ratio of the primary emulsion while maintaining constant other manufacturing parameters, desired porosity of microspheres that fill the pharmacokinetic requirements may be achieved [17].

\section{Materials and Methods}

KSL-W (sequence KKVVFWVKFK-CONH2), lot no. 05US1311-B, MW 1307, was custom synthesized by Synprep (Dublin, CA); PLGA 502H (poly (D,L-Lactide-co-glycolide 50:50 MW 11,300, lot no. STBB9327V); pharmaceutical grade polyvinyl alcohol low-viscosity, lot no. MKBD9933V, MW: 31,000-50,000, 98\%-99\% hydrolyzed were obtained from Sigma; Lutrol F127 (Pluronic F127), lot no. WPTF531B, was provided by Q.BASF; Mueller Hinton broth (Becton, Dickinson and Company, Spark, MD). All other chemicals used were analytical grade and were obtained from Sigma.

2.1. KSL-W Assay. KSL-W content of microspheres was determined by reverse-phase high-performance liquid chromatography (HPLC) using a Waters $600 \mathrm{E}$ multisolvent delivery system consisting of a Waters 600 pump and controller, a Waters 717 plus autosampler, and a Waters 996 photodiode array detector. The column used was a Prosphere C18-300 (4.6 $\times$ $250 \mathrm{~mm}, 5 \mu \mathrm{m}$ ). A gradient elusion was accomplished with acetonitrile: water : trifluoroacetic acid 10\%:90\%:0.1\% (A) and acetonitrile : water : trifluoroacetic acid 70\%:30\%:0.1\% (B) and increasing the amount of B from 0 to $100 \%$ over 20 minutes at a flow rate of $1.0 \mathrm{~mL} / \mathrm{min}$. Each sample was run for $35 \mathrm{~min}$ with a $5 \mathrm{~min}$ lag time between samples. KSL-W shows a peak at a retention time of $14.245 \mathrm{~min}$ (Figure 1). Standard curves of KSL-W ranging from $6.25 \mu \mathrm{g} / \mathrm{mL}$ to $1 \mathrm{mg} / \mathrm{mL}$ yielded linear responses over the concentration range with detection at $280 \mathrm{~nm}$ (Figure 2(a)). KSL-W release from microspheres incorporated in the gel was determined by UV spectrophotometry at $280 \mathrm{~nm}$ using an Eppendorf Biophotometer (Figure 2(b)).

2.2. Preparation of Microspheres. PLGA microspheres loaded with KSL-W were prepared by using the double-emulsification solvent evaporation method (W/O/W) [18-20], with PLGA 50:50, low-weight, and hydrophilic end, as the polymeric system. Three formulations having different organic to 


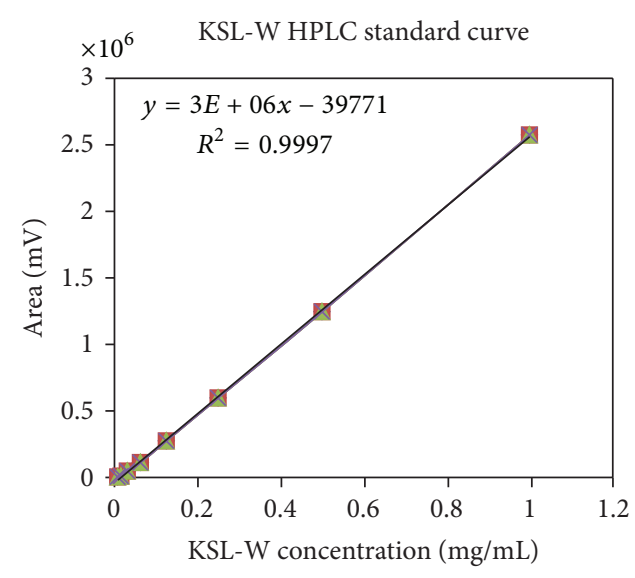

(a)

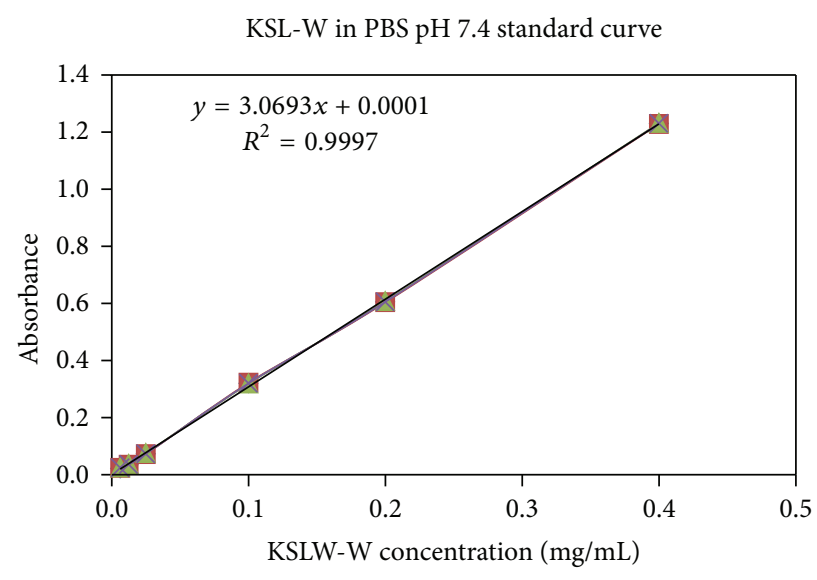

(b)

FIGURE 2: KSL-W standard curves $(280 \mathrm{~nm}$ ). (a) high-performance liquid chromatography; (b) UV spectrophotometry. Readings were obtained from samples determined in triplicates (mean \pm standard errors).

water ratio of the primary emulsion were prepared. Other conditions and variables applied for the preparation of KSL$\mathrm{W}$ microspheres were maintained constant. Formulations composition is shown in Table 1.

KSL-W was dissolved in deionized water and Tween 20 was added. The PLGA was dissolved in dichloromethane $\left(\mathrm{CH}_{2} \mathrm{Cl}_{2}\right)$. The KSL-W solution was slowly added to the PLGA solution to form a primary W/O emulsion by stirring with an Ultraturrax homogenizer at $24,000 \mathrm{rpm}$ for 5 minutes. The primary emulsion was slowly poured into $200 \mathrm{~mL}$ of $10 \times$ phosphate-buffered saline (10×-PBS), pH 7.4 containing 0.20 or $0.35 \%$ polyvinyl alcohol (PVA), and stirred at $1,800 \mathrm{rpm}$ (overhead propeller) for sufficient time to form microspheres. This allowed the $\mathrm{CH}_{2} \mathrm{Cl}_{2}$ to evaporate prior to filtration and rinsing. Figure 3 depicts this evaporation method for preparing microspheres. Following filtration and rinsing, the solidified microspheres were transferred from the filter to centrifuge tubes, washed three times with DIW, centrifuged at 2,500 rpm for $10 \mathrm{~min}$, and dried at $25^{\circ} \mathrm{C}$ under vacuum overnight.

2.3. Characterization of KSL-W/PLGA Microspheres. The characterization focused on comparing the porosity of the microspheres produced, and correlating such porosity to the in vitro release profiles of the final formulations. Determining how this porosity affected other MS parameters (surface morphology, particle size, drug content, loading efficiency $\%$, Yield \%) allowed a selection of the formulation(s) that guaranteed bactericidal activity of the delivery system for at least one week. The antimicrobial activity of the release fractions collected for each KSL-W microsphere formulation was determined against Staphylococcus epidermidis.

2.3.1. Microsphere Surface Morphology and Particle Size. Scanning electron microscopy (SEM) (Zeiss Field Emission, Sigma VP-40, Germany) was used to characterize the surface morphology of microspheres. Microspheres were mounted directly on the SEM stub using double stick carbon tape, coated with gold/palladium, and scanned in a high-vacuum chamber with a focused electron beam. Secondary electrons emitted from the sample were detected and the image was formed. The average particle size and size distribution were determined by using Smart Tiff from Zeiss.

2.3.2. Drug Content (KSL-W Content in the Microsphere Powder) (See [21]). Fifty mg of peptide loaded microspheres were quantitatively weighed and dissolved in $2 \mathrm{~mL}$ of $\mathrm{CH}_{2} \mathrm{CL}_{2}$, and the peptide was extracted with $10 \mathrm{~mL}$ of $0.1 \mathrm{M}$ acetate buffer with a $\mathrm{pH}$ of 4.0 by shaking for 1 hour in a wrist-action shaker. The aqueous buffer phase was separated by centrifugation, and the extracted peptide concentration was determined by reversed-phase HPLC

$$
\begin{aligned}
& \text { KSL-W in MS powder }(\% \mathrm{w} / \mathrm{w}) \\
& =\left[\mathrm{Cb}(\mathrm{mg} / \mathrm{mL}) \times \frac{10 \mathrm{~mL}}{50 \mathrm{mg}}\right] \times 100
\end{aligned}
$$

$\mathrm{Cb}=\mathrm{KSL}-\mathrm{W}$ concentration in acetate buffer $(\mathrm{mg} / \mathrm{mL})$.

\subsubsection{Loading Efficiency (\%)}

$$
\begin{aligned}
& \text { Loading efficiency }(\%) \\
& =\frac{\text { (total amount of KSL-W in microspheres) } \times 100}{\text { Amount of KSL-W initially weighed }} .
\end{aligned}
$$

2.3.4. Yield (\%). Obtained microspheres were weighed, and percentage yield was determined by using the following formula:

Yield (\%)

$$
=\left(\frac{\text { weight of MS obtained }}{\text { total weight of KSL-W and PLGA used }}\right) \times 100 \text {. }
$$




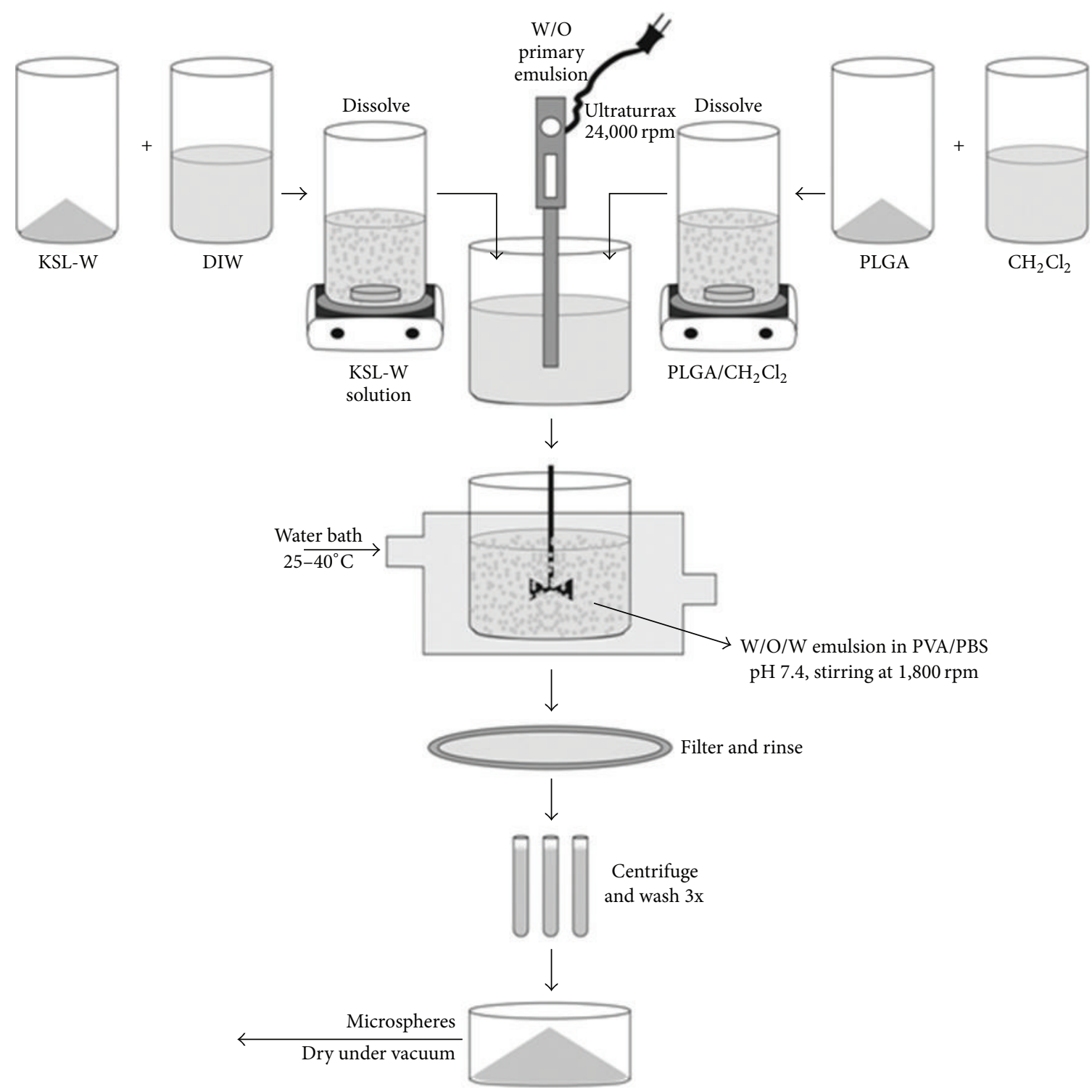

FIGURE 3: Schematic of the double-emulsification solvent extraction/evaporation method for the preparation of KSL-W-PLGA microspheres. Polycarbonate (PC) membrane filter ( $1 \mu \mathrm{m}$ size cutoff) was used to filter the MS.

\subsection{Preparation and Rheological Tests of Thermosensitive Formulations}

2.4.1. Preparation of Concentrated Pluronic (F127) Solution (See [22]). Aqueous 22.2\% pluronic F127 w/v was prepared by the cold method described by Schmolka [22]. The method involved slow addition of polymer in cold water with continuous agitation. The mixture was stored overnight at $4^{\circ} \mathrm{C}$ to obtain a clear solution.

2.4.2. Incorporation of MS in Pluronic (F127) Solution. Dried microspheres were resuspended in $2 \mathrm{~mL}$ distilled water. This suspension was added to the cold concentrated pluronic (F127) gel so that the final concentration of pluronic reached $20 \% \mathrm{w} / \mathrm{v}$ and gently stirred for $10 \mathrm{~min}$ for uniform distribution of MS in the pluronic.
2.4.3. Gelation Temperature (Tg) Measurement (See [23]). Ten $\mathrm{mL}$ of cold formulation and a magnetic stir bar were placed into a $25 \mathrm{~mL}$ glass vial that had been placed in a low-temperature water bath. A thermometer probe was immersed into the sample solution. The temperature was slowly increased $\left(2^{\circ} \mathrm{C} / \mathrm{min}\right)$ under continuous stirring. Temperature at which the magnetic bar stopped moving was reported as the gelation temperature $(\mathrm{Tg})$.

2.4.4. Viscosity Measurement (Centipoises, $c P$ ). Formulation viscosities were measured using a low viscosity Brookfield viscometer (model LVDV-E-115, Cole Palmer, Vernon Hills, IL, USA) with a small sample volume adapter and spindles no. 61 (for low viscosity) and no. 34 (for higher viscosity). Viscosity of formulations was measured at seven different temperatures. These included the gelation temperature $(\mathrm{Tg})$, 
TABLE 1: KSL-W/PLGA microspheres: composition of formulations and manufacturing parameters.

\begin{tabular}{|c|c|c|c|c|c|c|}
\hline Formulation & $\begin{array}{c}\text { PLGA } \\
(\mathrm{mg})\end{array}$ & $\begin{array}{c}\left(\mathrm{CH}_{2} \mathrm{Cl}_{2}\right) \\
(\mathrm{mL}) \\
\end{array}$ & $\begin{array}{c}\text { KSL-W } \\
(\mathrm{mg})\end{array}$ & $\begin{array}{l}\text { KSL-W } \\
\text { Solvent }\end{array}$ & $\begin{array}{c}\text { PVA \% } \\
(\mathrm{w} / \mathrm{v})\end{array}$ & $\begin{array}{l}\text { Stirring } \\
\left({ }^{\circ} \mathrm{C}\right) \text { Time }\end{array}$ \\
\hline A & 600 & 20 & 200 & $\begin{array}{c}2 \mathrm{~mL} \text { DIW } \\
0.1 \mathrm{~mL} \text { Tween } 20\end{array}$ & 0.35 & $\begin{array}{l}25^{\circ} \mathrm{C} 30 \mathrm{~m} \\
40^{\circ} \mathrm{C} 1 \mathrm{hr}\end{array}$ \\
\hline B & 600 & 20 & 200 & $4 \mathrm{~mL}$ DIW $+0.1 \mathrm{~mL}$ Tween 20 & 0.35 & $\begin{array}{l}25^{\circ} \mathrm{C} 30 \mathrm{~m} \\
40^{\circ} \mathrm{C} 1 \mathrm{hr}\end{array}$ \\
\hline $\mathrm{C}$ & 600 & 20 & 200 & $3 \mathrm{~mL}$ DIW $+0.1 \mathrm{~mL}$ Tween 20 & 0.35 & $\begin{array}{l}25^{\circ} \mathrm{C} 30 \mathrm{~m} \\
40^{\circ} \mathrm{C} 1 \mathrm{hr}\end{array}$ \\
\hline
\end{tabular}

*DIW: deionized water.

four temperatures below the $\mathrm{Tg}$, and two temperatures above the Tg. The principle of operation of the DV-E viscometers is to rotate a spindle (immersed in the test fluid) through a calibrated spring. The viscous drag of the fluid against the spindle is measured by the spring deflection in centipoises $(\mathrm{cP})$ or millipascal seconds $(\mathrm{mPa} \cdot \mathrm{s}) .1 \mathrm{cP}=1 \mathrm{mPa} \cdot \mathrm{s}$.

\subsection{In Vitro Release Profile and Bactericidal Activity of Final Formulations}

2.5.1. In Vitro Release Profile (See [24-26]). In vitro release profile of KSL-W from the PLGA microspheres suspended in PBS and in 20\% Pluronic F127 gel was performed in triplicate for each formulation using a six-station Franz diffusion cell. A half of a $\mathrm{mL}$ of each microsphere suspension was placed into each corresponding donor chamber of the instrument. The donor chamber was separated from the acceptor chamber by a $0.1-\mu \mathrm{m}$ polycarbonate (PC) membrane. The medium solution in the acceptor chamber was $5 \mathrm{~mL}$ PBS at $\mathrm{pH} 7.4$. Acceptor chamber was kept at $37^{\circ} \mathrm{C}$ (circulating water) and was continuously stirred (magnetic stirrer). Release samples of $0.2 \mathrm{~mL}$ were removed at different intervals $(1,2,4,6$, and 12 hours and 1 to 7 days) from the acceptor chamber. The volume of the sample removed was replaced with the same volume of fresh buffer after each sampling. KSL-W content was evaluated by a UV-Vis spectrophotometer at $280 \mathrm{~nm}$, and the amount of KSL-W was determined by extrapolation in a previously prepared calibration curve.

2.5.2. Bactericidal Activity (See [27]). Bactericidal activity was determined against Staphylococcus epidermidis using the broth microdilution method. Freshly grown cultures of Staphylococcus epidermidis at exponential phase were used as the inoculum. Bacteria were centrifuged at 4,000 rpm for $15 \mathrm{~min}$ at $4^{\circ} \mathrm{C}$, suspended in $2 \times$ Mueller Hinton broth, and adjusted to approximately $4 \times 10^{6}$ colony-forming units ( $\mathrm{cfu}$ ) per milliliter in $2 \times$ Mueller Hinton broth. Release sample $(100 \mu \mathrm{L})$ was added to each well of a 96-well, flat-bottomed plate (Becton Dickinson, Spark, MD, USA). The solution was serially diluted (twofold) with sterile distilled water in the wells. Aqueous KSL-W peptide at $200 \mu \mathrm{g}$ per mL, which served as the positive control, was included in the assay and serially diluted in sterile distilled water as the release sample. After dispensing $100-\mu \mathrm{L}$ aliquots of bacterial suspension into the wells, the 96 -well plates were incubated at $37^{\circ} \mathrm{C}$ for 24 hours. The minimum inhibitory concentration (MIC) was defined as the lowest concentration of the release sample (containing released peptide) or KSL-W peptide solution that prevented visible turbidity, as measured at $600 \mathrm{~nm}$ by using an ELISA reader (BIOTEK, Winooski, VT, USA).

\section{Results and Discussion}

Table 1 shows that differences in composition of formulations $\mathrm{A}, \mathrm{B}$, and $\mathrm{C}$ are only in the amount of water used to dissolve the peptide in the $\mathrm{O} / \mathrm{W}$ primary emulsion. Other variables and manufacturing parameters have remained constant; therefore, we can assume that differences in properties of the obtained MS are due to differences in the organic to water $(\mathrm{O} / \mathrm{W})$ ratio of their initial composition.

The scanning electron micrographs (SEMs) are shown in Figures 4, 5, and 6. The microparticles were spherical for the three formulations and essentially free of aggregation. Surface morphology showed smooth surfaces with varying porosity from low for Formulation A to high for B and C, with $\mathrm{C}$ being the highest. Fractured particles of $A$ and $B$ reveal a very porous interior.

The properties and characteristics of the peptide-loaded PLGA microspheres are tabulated in Table 2. Yields ranged from 68 to $84 \%$ with loading efficiencies of $68-78 \%$ and drug contents of 17-20\%. The average particle size as determined from the SEMs was $46.42 \mu \mathrm{m} \pm 17.9 \mu \mathrm{m}$ for Formulation A (Figure 7(a)), 25.8 $\mu \mathrm{m} \pm 14.1 \mu \mathrm{m}$ for $02-15$ (Figure 7(b)) and $40 \mu \mathrm{m} \pm 12.8 \mu \mathrm{m}$ for C (Figure $7(\mathrm{c})$ ). Surface area measurements were not performed but formulation $\mathrm{A}$, due to larger particle size, would have the lowest surface area, while $C$ would have a higher surface area than $\mathrm{A}$ but lower than $\mathrm{B}$ which has the smallest particle size.

In vitro release of KSL-W from the microspheres suspended in PBS and in 20\% Pluronic 127 is listed in Table 2 at 150 hours for comparative purposes, since a delivery system lasting 4 to 7 days in a wound is necessary. As shown in Figure 8, more than 60\% was released in 150 hours for the three formulations with B showing the highest release, $74.8 \%$ in PBS and $76.3 \%$ in the gel. There is no detectable burst release difference of MS formulations in Pluronic F127 $20 \%$ gel. But the release for A decreased considerably after 96 hours in this medium. The subsequent slower rate is understandable considering the larger particle size and lower porosity for A, giving rise to lower specific surface area and a resulting lower polymer degradation rate.

Release of the peptide from the microsphere is controlled by two mechanisms: diffusion of the protein out of 


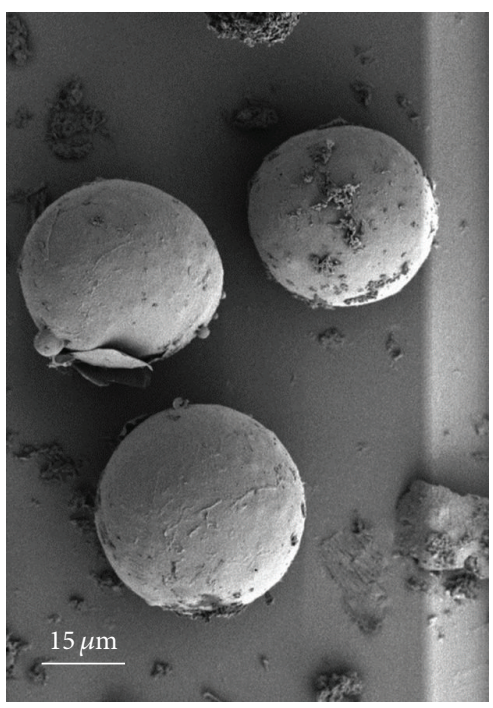

(a)

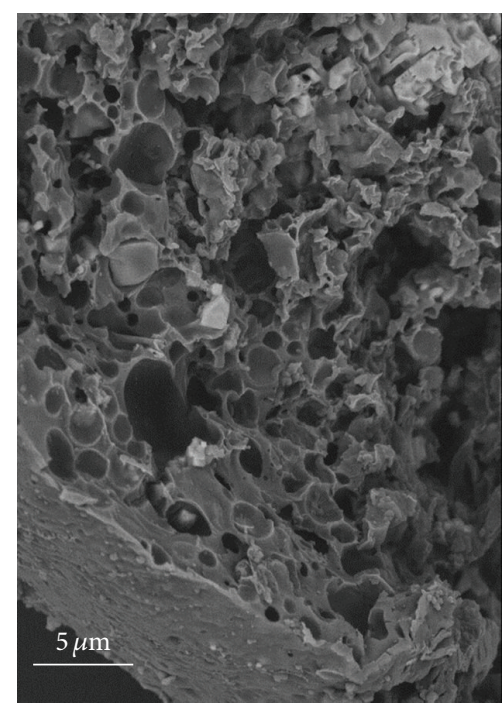

(b)

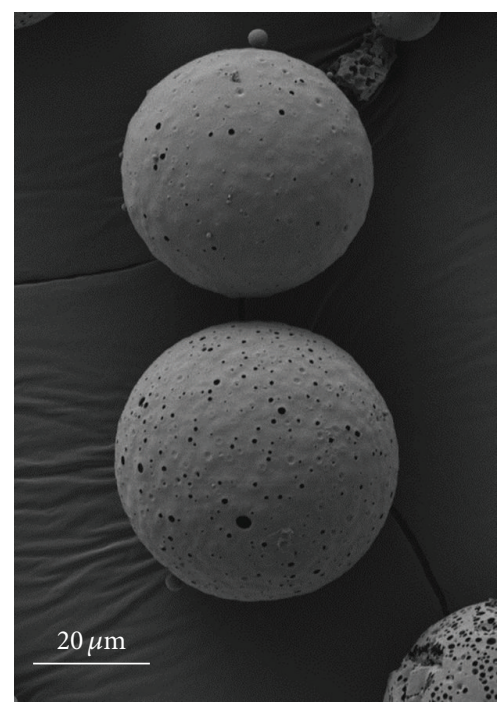

(c)

FIGURE 4: SEM images of microsphere Formulation A.

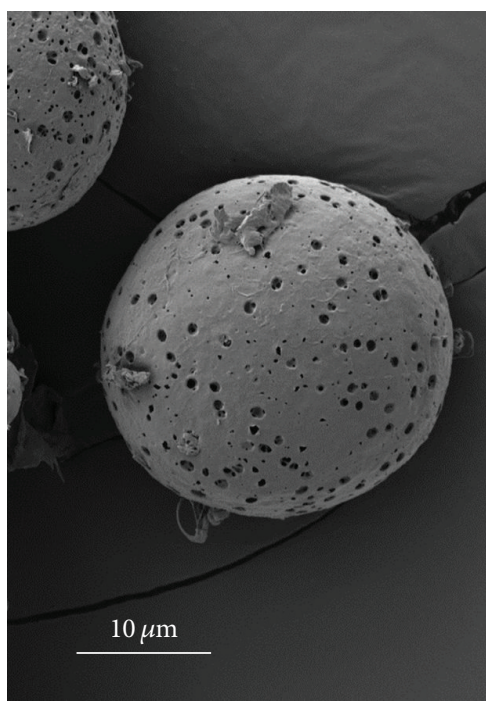

(a)

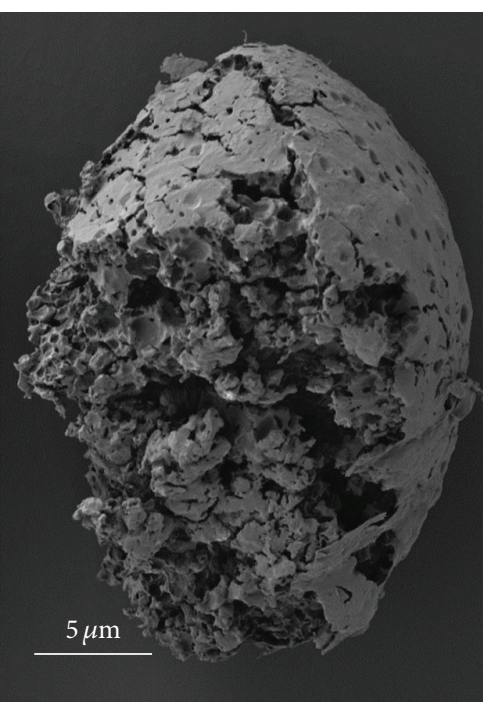

(b)

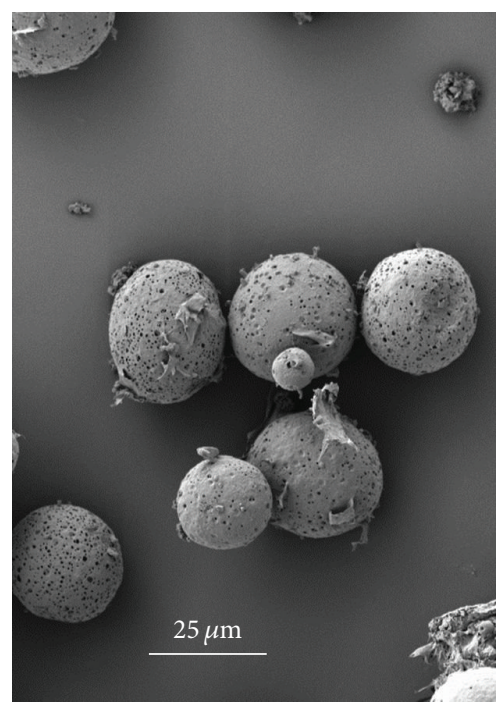

(c)

FIgURE 5: SEM images of microsphere Formulation B.

TABLE 2: KSL-W microsphere properties.

\begin{tabular}{|c|c|c|c|c|c|c|c|}
\hline \multirow{2}{*}{ Formulation } & \multirow{2}{*}{$\begin{array}{l}\text { Surface } \\
\text { morphology }\end{array}$} & \multirow{2}{*}{ Yield (\%) } & \multirow{2}{*}{ KSL-W content (\%) } & \multirow{2}{*}{$\begin{array}{l}\text { Loading efficiency } \\
(\%)\end{array}$} & \multirow{2}{*}{$\begin{array}{l}\text { average size }(\mu \mathrm{m}) \\
\quad n=30\end{array}$} & \multicolumn{2}{|c|}{$\%$ Release at 150 hours } \\
\hline & & & & & & In PBS & In Gel \\
\hline A & $\begin{array}{l}\text { Spherical, } \\
\text { high surface } \\
\text { porosity }\end{array}$ & 75 & 17 & 68 & $46.4 \pm 17.9$ & $52.0 \pm 2.5$ & $64.4 \pm 2.7$ \\
\hline B & $\begin{array}{l}\text { Spherical, } \\
\text { high surface } \\
\text { porosity }\end{array}$ & 84 & 19 & 77 & $25.8 \pm 14.1$ & $74.8 \pm 2.3$ & $76.3 \pm 1.2$ \\
\hline $\mathrm{C}$ & $\begin{array}{l}\text { Spherical, } \\
\text { high surface } \\
\text { porosity }\end{array}$ & 68 & 20 & 78 & $40.0 \pm 12.8$ & $53.3 \pm 4.5$ & $68.3 \pm 3.6$ \\
\hline
\end{tabular}




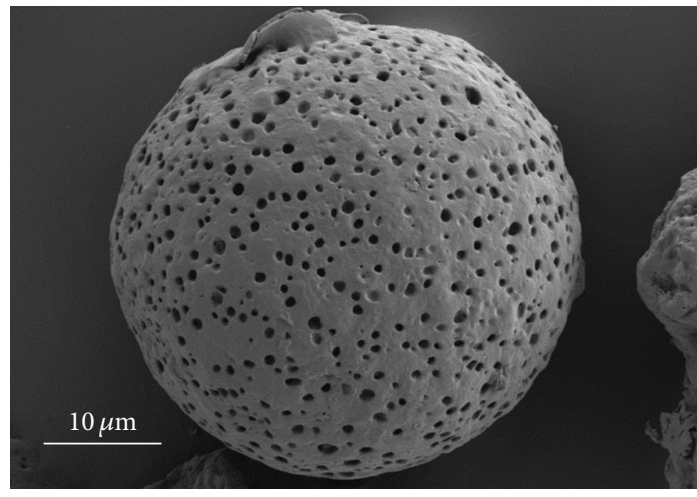

(a)

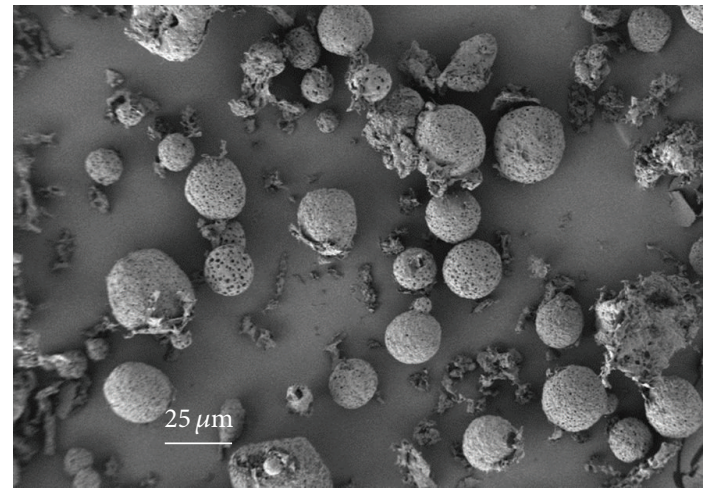

(b)

FIgure 6: SEM images of microsphere Formulation C.

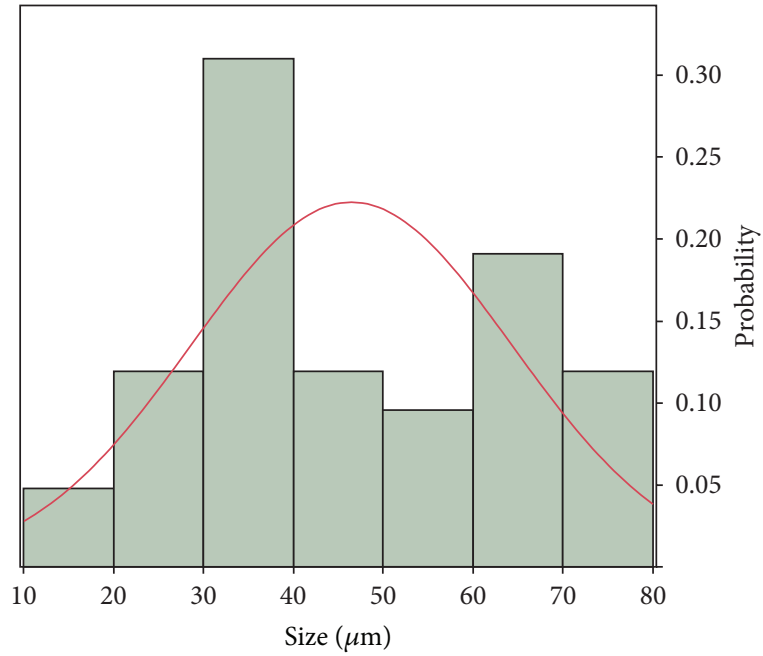

(a)

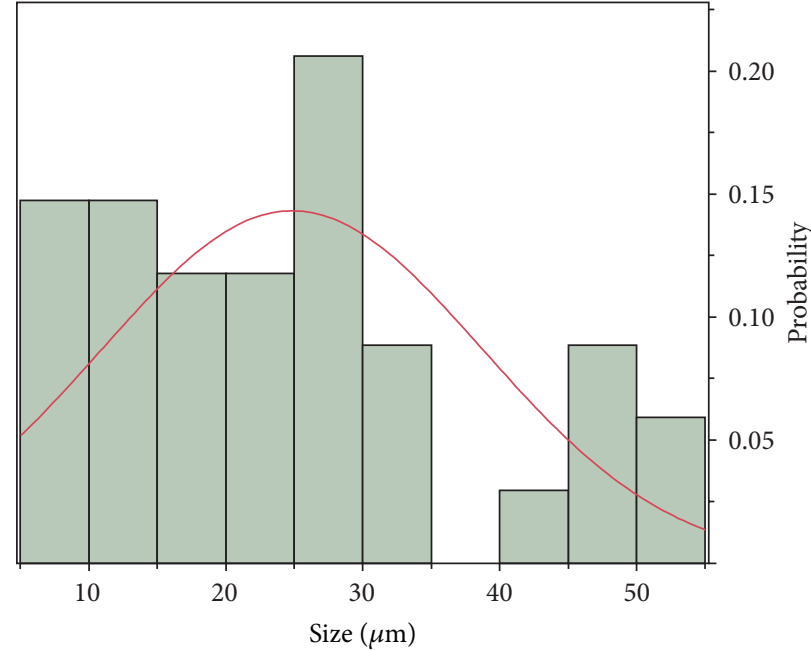

(b)

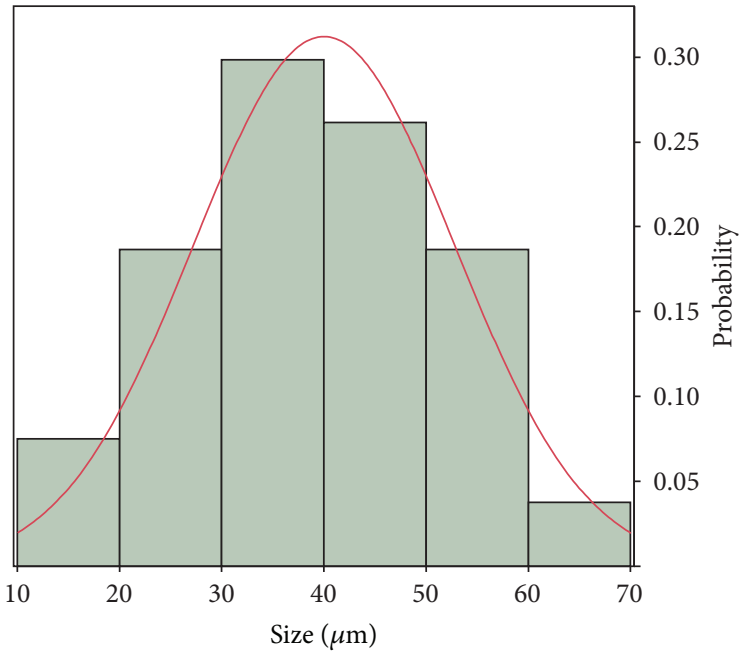

(c)

Figure 7: KSL-W PLGA microspheres particle size and particle size distribution using Smart Tiff from Zeiss; $n=30$. Average means; Formulation A, $46.4 \mu \mathrm{m} \pm 17.9 \mu \mathrm{m}$; Formulation B, $25.8 \mu \mathrm{m} \pm 14.1 \mu \mathrm{m}$; Formulation C, $40.0 \mu \mathrm{m} \pm 12.8 \mu \mathrm{m}$. 


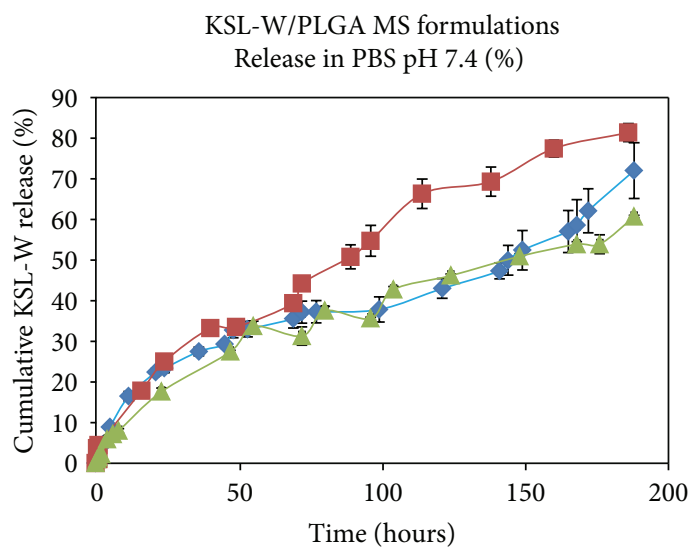

(a)

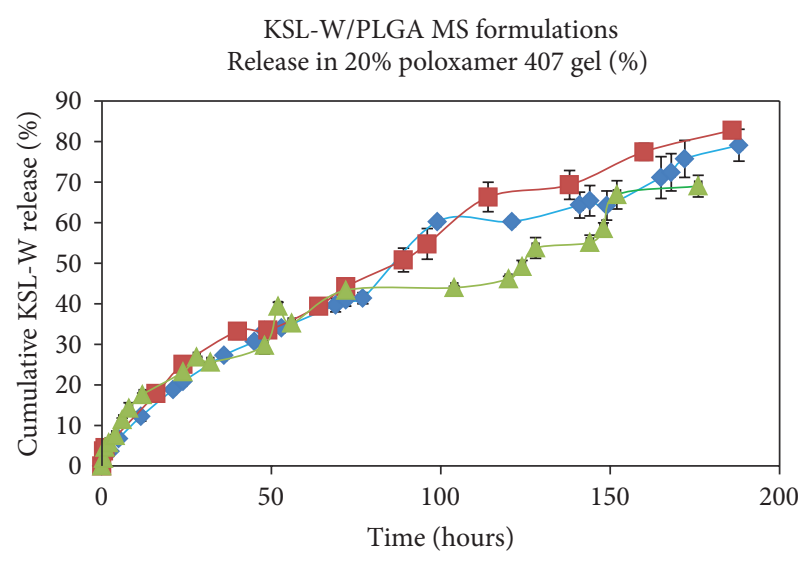

(b)

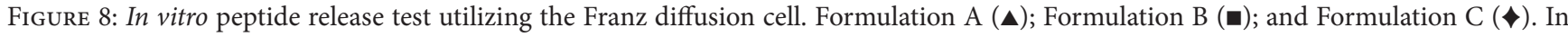
all samples, $n=3$. Membrane filter: $0.1 \mu \mathrm{m}$ PC. Acceptor media: $5 \mathrm{~mL}$ PBS pH 7.4. Sampling volume: $0.2 \mathrm{~mL}$. Sample size in donor chamber: $0.5 \mathrm{~mL}$.

the microsphere and erosion of the polymer matrix. Typically, the diffusion process consists of an initial "burst" release of peptide at or near the surface of the microsphere followed by the additional release of protein from the pores of the microsphere. Erosion occurs by hydrolysis of the polymer matrix generating pores that expose interior pockets of peptide to the bathing liquid. For continuous release, the diffusion and erosion process must balance each other to allow the peptide to diffuse out of the microsphere at a constant rate.

The formulations produced in this study did not yield a complete release of the peptide. A number of reasons could cause the incomplete release when double-emulsion/solvent evaporation method is being used as in this study. For example, one of the possible causes for the incomplete release observed might be due to nonspecific adsorption of peptides to interfaces or to microsphere materials. In addition, the peptide could potentially be denatured or degraded when exposed to a variety of stress conditions including heat, shear, and organic solvents exposure during the preparation of microspheres.

Even though not very high in our case, in general, hydrophilic polymers in the formulations result in a high initial burst and high release rates when PLGA with relatively high glycolide content (50/50) is used [28]. The higher glycolide content makes the polymer more hydrophilic and facilitates water uptake from the release medium. The PLGA used in the formulations (D,L-Lactide-glycolide $50: 50$, acid terminated, MW 7,000 to 17000 from Sigma) corresponds to Resomer RG $502 \mathrm{H}$, a PLGA carrying free carboxylic end groups that resulted in a higher incorporation efficiency, as well as a higher hydration, as compared to the end-capped polymer [29].

Release from both $\mathrm{B}$ and $\mathrm{C}$ microsphere formulations was continuous with $\mathrm{B}$ showing a similar release profile in both PBS and the Pluronic gel. What is difficult to explain is the similar release for B in PBS and in the gel, while for C release was greater in the gel. Evidently, hydration in the gel may be greater or the pluronic may accelerate the polymer degradation. Nevertheless, a release of $75 \%$ at 150 hours from the B microspheres in both PBS and the Pluronic gel suggests that this is the preferable formulation to pursue as a woundhealing device.

Table 3 and Figure 9 show that the gelation temperature and viscosity of formulations $\mathrm{A}, \mathrm{B}$, and $\mathrm{C}$ were very close to those of the blank formulation (pluronic F127 20\% solution containing no MS powder) suggesting that MS powder did not interfere with the rheological properties of the carrier. Ideally an in situ gelling system used in an open wound or burned skin should be low in viscosity as a free flowing liquid to allow for easy and accurate topical administration to the injured site. The gel formed following phase transition at body temperature should be strong enough to remain on the site and exhibits a long residence time. This provides a platform for a continued and sustained release of the loaded drug to enhance bioavailability, reduce systemic absorption, and the need for frequent administration leading to improved patient compliance [30]. The formulations reported in this study possess some of these properties. However, future efforts will be to increase the gelation temperature of the formulations to broaden their application to meet various extreme ambient temperatures.

Antimicrobial activity of the release fraction collected for each KSL-W microsphere formulation as determined against staphylococcus epidermidis using the broth microdilution method is shown in Figure 10. After proper dilution of each collected fraction for the starting concentration in the bactericidal assay, all three microsphere formulations (Formulations A, B, and C) tested showed antimicrobial activity (MIC around $6.25 \mu \mathrm{g} / \mathrm{mL}$ ). S. epidermidis, one of the most prevalent bacteria found on human skin and mucous membrane microbial flora, has emerged as major source of nosocomial infections of implanted devices. These coagulasenegative staphylococci readily form biofilms on surfaces.

\section{Summary and Conclusion}

Utilizing a thermosensitive gel, the sustained release of an antimicrobial peptide, KSL-W, in porous, hydrophilic, 


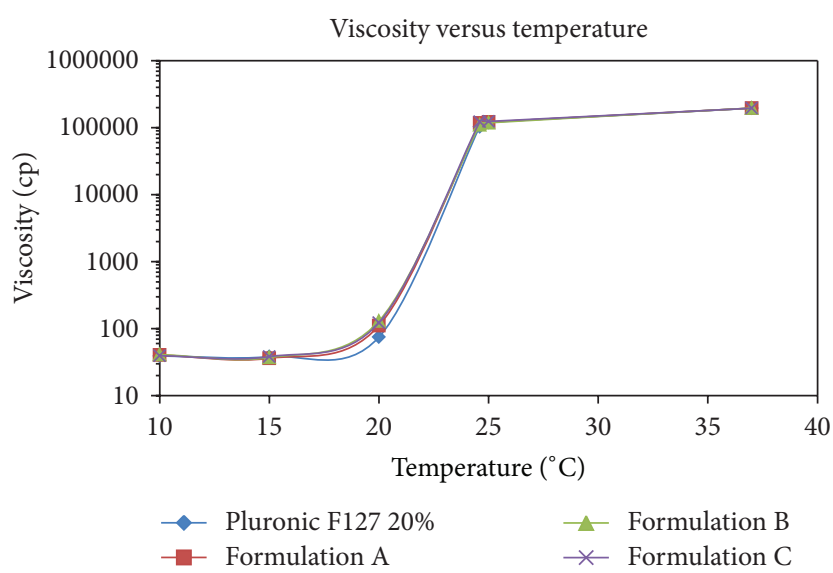

FIGURE 9: Viscosity profiles of formulations prepared from pluronic F127 as a function of temperature. Formulation A ( $\mathbf{\Delta}$ ); Formulation B

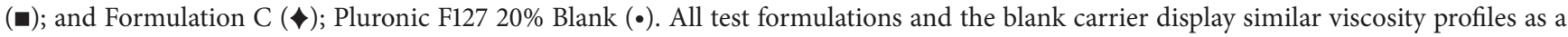
function of the temperature. Readings (mean \pm standard deviations) are from samples tested in triplicates.

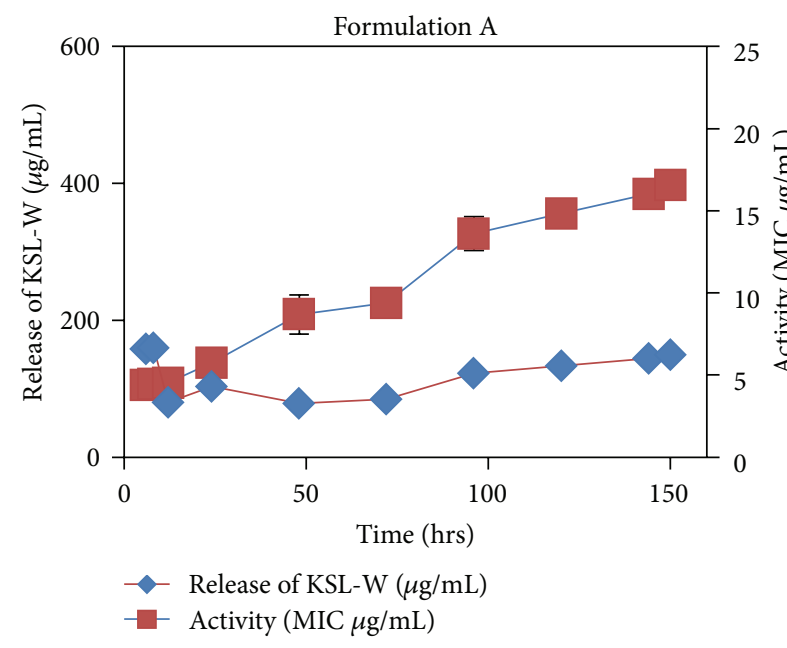

(a)

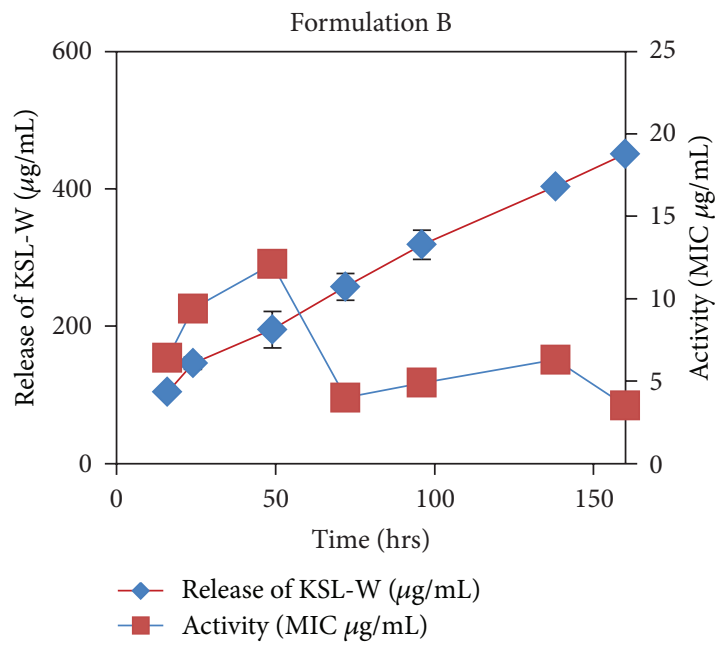

(b)

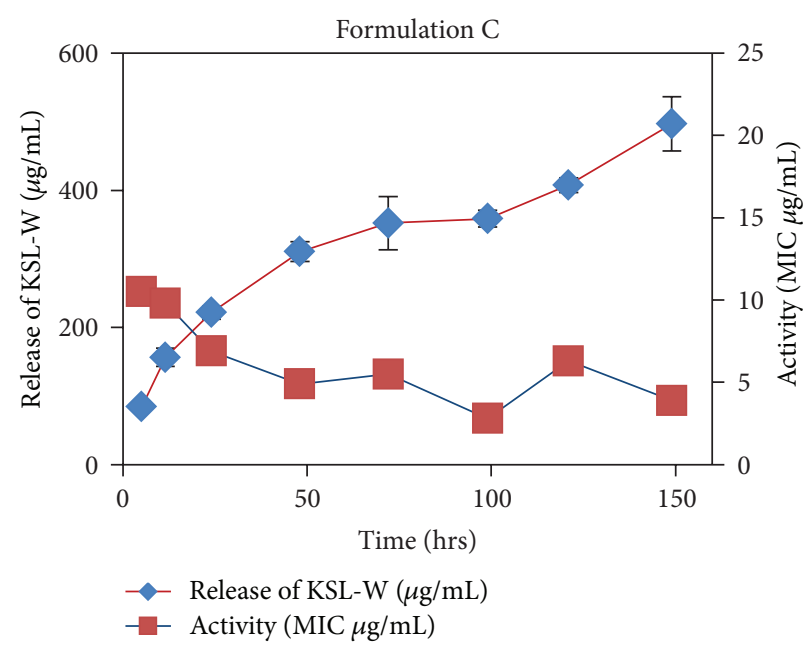

(c)

FIGURE 10: Bactericidal activity of fractions collected from KSL-W PLGA microsphere formulation release using the broth microdilution method. The MIC of KSL-W peptide alone against S. epidermidis was $6.25 \mu \mathrm{g} / \mathrm{mL}$. 
TABLE 3: Gelation temperature (Tg), viscosity, and $\mathrm{pH}$ of Formulations.

\begin{tabular}{|c|c|c|c|c|c|c|c|c|}
\hline \multirow{2}{*}{$\begin{array}{l}\text { Formulation } \\
\text { code }\end{array}$} & \multirow{2}{*}{$\begin{array}{l}\text { Gelation temp. } \\
\text { (Tg): }{ }^{\circ} \mathrm{C}\end{array}$} & \multicolumn{6}{|c|}{ Viscosity (cp) } & \multirow{2}{*}{$\mathrm{pH}$} \\
\hline & & $10^{\circ} \mathrm{C}$ & $15^{\circ} \mathrm{C}$ & $20^{\circ} \mathrm{C}$ & $24.6^{\circ} \mathrm{C}$ & $25^{\circ} \mathrm{C}$ & $37^{\circ} \mathrm{C}$ & \\
\hline Blank $^{* €}$ & & $39.2 \pm 1.5$ & $38.2 \pm 0.2$ & $75.0 \pm 2.5$ & $103,820.0 \pm 16.2$ & $120,216.7 \pm 46.4$ & $195,616.7 \pm 224.8$ & $6.6 \pm 0.2$ \\
\hline $\mathrm{A}^{€}$ & $24.7 \pm 0.2$ & $40.5 \pm 0.2$ & $36.2 \pm 0.2$ & $111.0 \pm 2.9$ & $117,426.7 \pm 90.0$ & $121,533.3 \pm 205.5$ & $196,133.3 \pm 249.4$ & $6.5 \pm 0.1$ \\
\hline$B^{€}$ & $24.6 \pm 0.1$ & $41.0 \pm 0.5$ & $37.1 \pm 0.2$ & $130.0 \pm 13.0$ & $110,400.0 \pm 294.3$ & $118,485.3 \pm 283.8$ & $196,500.0 \pm 294.4$ & $6.4 \pm 0.2$ \\
\hline $\mathrm{C}^{€}$ & $24.7 \pm 0.1$ & $34.5 \pm 0.6$ & $38.3 \pm 0.4$ & $122.7 \pm 3.9$ & $122,400.0 \pm 374.2$ & $124,216.7 \pm 201.4$ & $195,666.7 \pm 0.4$ & $6.7 \pm 0.1$ \\
\hline
\end{tabular}

*Pluronic F127 20\% solution.

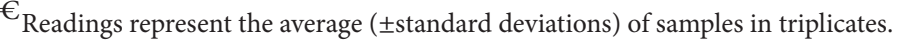

low molecular weight polylactide-co-glycolide microspheres provided antimicrobial activity for up to one week. All three formulations produced showed a similar gelation profile as compared to that of the carrier. Fractions collected from the in vitro release media of the three formulations studied showed antimicrobial activity against the targeted microorganism Staphylococcus epidermidis. These results suggest that a KSL-W microsphere in 20\% Pluronic F127 gel has considerable potential as a delivery system for achieving antimicrobial activity and effective wound healing in combatrelated injuries. Formulation B was selected as the choice for further characterization based on the total percent release (Figure 8) which is higher than formulations A \& C. In addition, formulation $\mathrm{B}$ possesses the smallest particle size among all three formulations (Figure 7).

\section{Disclaimer}

Some of the authors (J. J. Abercrombie and K. P. Leung) are employees of the US Government. The work presented is part of their official duties. The opinions or assertions contained herein are the private views of these authors and are not to be construed as official or as reflecting the views of the Department of the Army or the Department of Defense.

\section{Conflict of Interests}

The authors declare that there is no conflict of interests.

\section{Acknowledgments}

This work was partly supported by the US Army Medical Research and Materiel Command, Military Infectious Diseases, and Combat Casualty Care Research Directorates.

\section{References}

[1] C. K. Murray, "Infectious disease complications of combatrelated injuries," Critical Care Medicine, vol. 36, no. 7, pp. S358S364, 2008.

[2] J. B. Peravali, S. R. Kotra, K. Sobha, R. Nelson, K. V. Rajesh, and K. K. Pulicherla, "Antimicrobial peptides, an effective alternative for antibiotic therapy," Mintage Journal of Pharmaceutical and Medical Sciences, vol. 2, no. 2, pp. 1-7, 2013.

[3] D. H. Na, J. Faraj, Y. Capan, K. P. Leung, and P. P. DeLuca, "Stability of antimicrobial decapeptide (KSL) and its analogues for delivery in the oral cavity," Pharmaceutical Research, vol. 24, no. 8, pp. 1544-1550, 2007.

[4] J. A. Faraj, R. Dorati, A. Schoubben et al., "Development of a peptide-containing chewing gum as a sustained release antiplaque antimicrobial delivery system," AAPS PharmSciTech, vol. 8, no. 1, article 26, 2007.

[5] S. H. Marshall and G. Arenas, "Antimicrobial peptides: a natural alternative to chemical antibiotics andapotential for applied biotechnology," Electronic Journal of Biotechnology, vol. 6, no. 3, pp. 271-284, 2003.

[6] R. L. Williams, H. Y. Sroussi, J. J. Abercrombie, K. Leung, and P. T. Marucha, "Synthetic decapeptide reduces bacterial load and accelerates healing in the wounds of restraint-stressed mice," Brain, Behavior, and Immunity, vol. 26, no. 4, pp. 588-596, 2012.

[7] H. K. Makadia and S. J. Siegel, "Poly Lactic-co-Glycolic Acid (PLGA) as biodegradable controlled drug delivery carrier," Polymers, vol. 3, no. 3, pp. 1377-1397, 2011.

[8] S. B. Murty, Q. Wei, B. C. Thanoo, and P. P. DeLuca, "In vivo release kinetics of octreotide acetate from experimental polymeric microsphere formulations using oil/water and oil/oil processes," AAPS PharmSciTech, vol. 5, no. 3, pp. 90-99, 2004.

[9] K. R. Chaudhari, N. Shah, H. Patel, and R. Murthy, "Preparation of porous PLGA microspheres with thermoreversible gel to modulate drug release profile of water-soluble drug: bleomycin sulphate," Journal of Microencapsulation, vol. 27, no. 4, pp. 303313, 2010.

[10] R. C. Mehta, B. C. Thanoo, and P. P. DeLuca, "Peptide containing microspheres from low molecular weight and hydrophilic poly(d,1-lactide-co-glycolide)," Journal of Controlled Release, vol. 41, no. 3, pp. 249-257, 1996.

[11] H. R. Patel, R. P. Patel, and M. M. Patel, "Poloxamers: a pharmaceutical excipients with therapeutic behaviors," International Journal of PharmTech Research, vol. 1, no. 2, pp. 299-303, 2009.

[12] J. J. Escobar-Chávez, M. López-Cervantes, A. Naïk, Y. N. Kalia, D. Quintanar-Guerrero, and A. Ganem-Quintanar, "Applications of thermo-reversible pluronic F-127 gels in pharmaceutical formulations," Journal of Pharmacy \& Pharmaceutical Sciences, vol. 9, no. 3, pp. 339-358, 2006.

[13] B. Fussnegger, "Poloxamers (2): lutrol F127 (poloxamer 407)," BASF ExAct, vol. 4, article 7, 2000.

[14] Y. Yeo and K. Park, "Control of encapsulation efficiency and initial burst in polymeric microparticle systems," Archives of Pharmacal Research, vol. 27, no. 1, pp. 1-12, 2004.

[15] L. E. Bromberg and E. S. Ron, "Temperature-responsive gels and thermogelling polymer matrices for protein and peptide delivery," Advanced Drug Delivery Reviews, vol. 31, no. 3, pp. 197221, 1998. 
[16] F. Ganji and E. Vasheghani-Farahani, "Hydrogels in controlled drug delivery systems," Iranian Polymer Journal, vol. 18, no. 1, pp. 63-88, 2009.

[17] G. Crotts and T. G. Park, "Preparation of porous and nonporous biodegradable polymeric hollow microspheres," Journal of Controlled Release, vol. 35, no. 2-3, pp. 91-105, 1995.

[18] R. Alex and R. Bodmeier, "Encapsulation of water-soluble drugs by a modified solvent evaporation method. I: effect of process and formulation variables on drug entrapment," Journal of Microencapsulation, vol. 7, no. 3, pp. 347-355, 1990.

[19] R. Jeyanthi, R. C. Mehta, B. C. Thanoo, and P. P. DeLuca, "Effect of processing parameters on the properties of peptidecontaining PLGA microspheres," Journal of Microencapsulation, vol. 14, no. 2, pp. 163-174, 1997.

[20] J. W. Kostanski, B. C. Thanoo, and P. P. DeLuca, "Preparation, characterization, and in vitro evaluation of 1- and 4-month controlled release orntide PLA and PLGA microspheres," Pharmaceutical Development and Technology, vol. 5, no. 4, pp. 585596, 2000.

[21] K. W. Burton, M. Shameem, B. C. Thanoo, and P. P. DeLuca, "Extended release peptide delivery systems through the use of PLGA microsphere combinations," Journal of Biomaterials Science, vol. 11, no. 7, pp. 715-729, 2000.

[22] I. R. Schmolka, "Artificial skin. I. Preparation and properties of pluronic F-127 gels for treatment of burns," Journal of Biomedical Materials Research, vol. 6, no. 6, pp. 571-582, 1972.

[23] E.-S. A. Ibrahim, S. Ismail, G. Fetih, O. Shaaban, K. Hassanein, and N. H. Abdellah, "Development and characterization of thermosensitive pluronic-based metronidazole in situ gelling formulations for vaginal application," Acta Pharmaceutica, vol. 62, no. 1, pp. 59-70, 2012.

[24] K. D. Thakker and W. H. Chern, "Development and validation of in vitro release test for semisolid dosage forms-case study," Dissolution Technologies, pp. 10-15, 2003.

[25] Q. Fan, M. Mitchnick, and A. Loxley, "In vitro release testing: the issues and challenges involved in in vitro release testing for semi-solid," Drug Delivery Tech, vol. 7, no. 9, pp. 62-66, 2007.

[26] L. C. Herrera, M. V. D. Tesoriero, and L. G. Hermida, "In vitro release testing of PLGA microspheres with Franz diffusion cells," Dissolution Technologies, vol. 19, no. 2, pp. 6-11, 2012.

[27] L. Otvos and M. Cudic, "Broth microdilution antibacterial assay of peptides," Methods in Molecular Biology, vol. 386, pp. 309320, 2007.

[28] D. T. O'Hagan, H. Jeffery, and S. S. Davis, “The preparation and characterization of PLGA microspheres: III. Microparticle/polymer degradation rates and the in vitro release of a model protein," International Journal of Pharmaceutics, vol. 103, no. 1, pp. 37-45, 1994.

[29] E. Walter, D. Dreher, M. Kok et al., "Hydrophilic poly(DLlactide-co-glycolide) microspheres for the delivery of DNA to human-derived macrophages and dendritic cells," Journal of Controlled Release, vol. 76, no. 1-2, pp. 149-168, 2001.

[30] I. P. Kaur, M. Singh, and M. Kanwar, "Formulation and evaluation of ophthalmic preparations of acetazolamide," International Journal of Pharmaceutics, vol. 199, no. 2, pp. 119-127, 2000. 

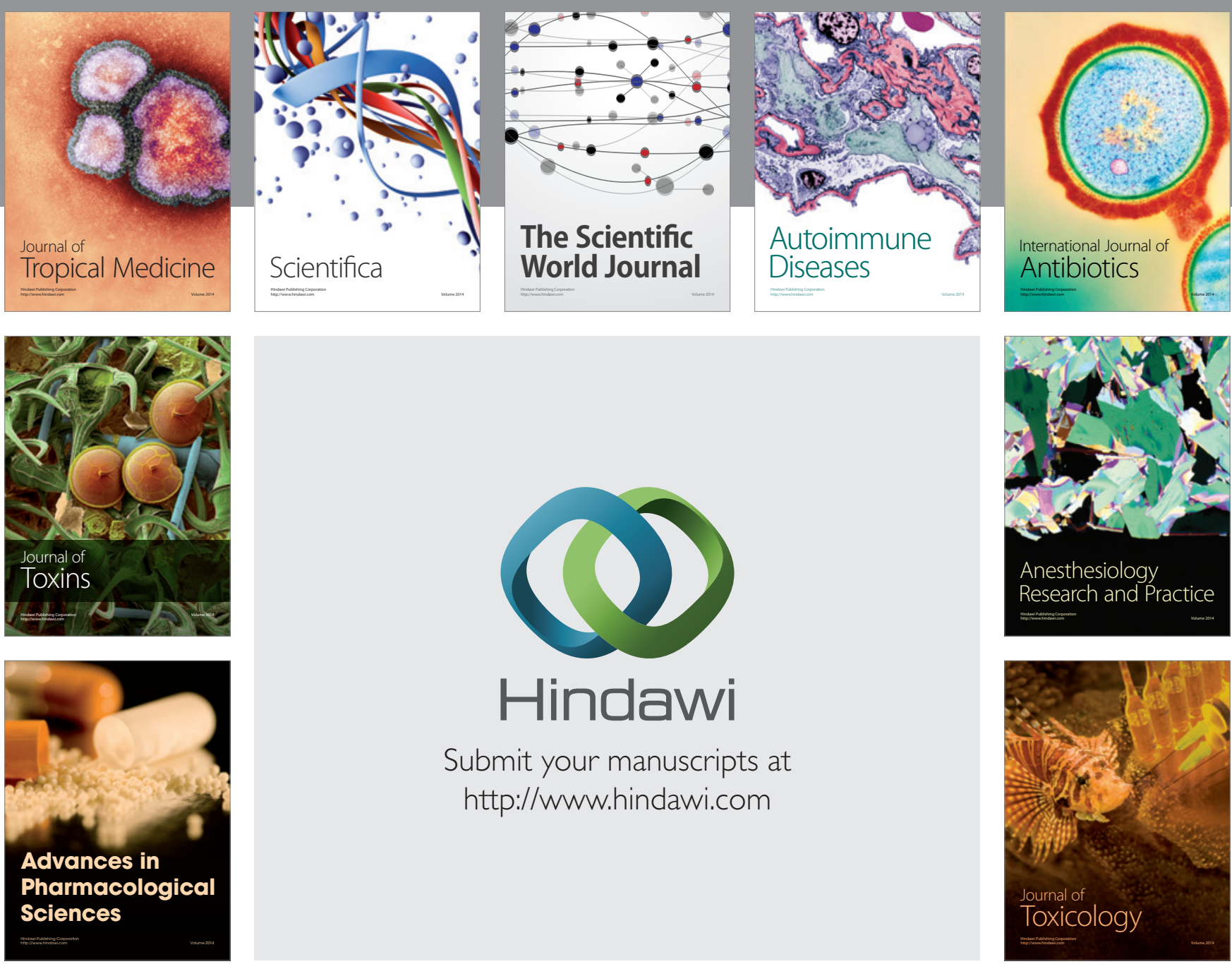

\section{Hindawi}

Submit your manuscripts at

http://www.hindawi.com
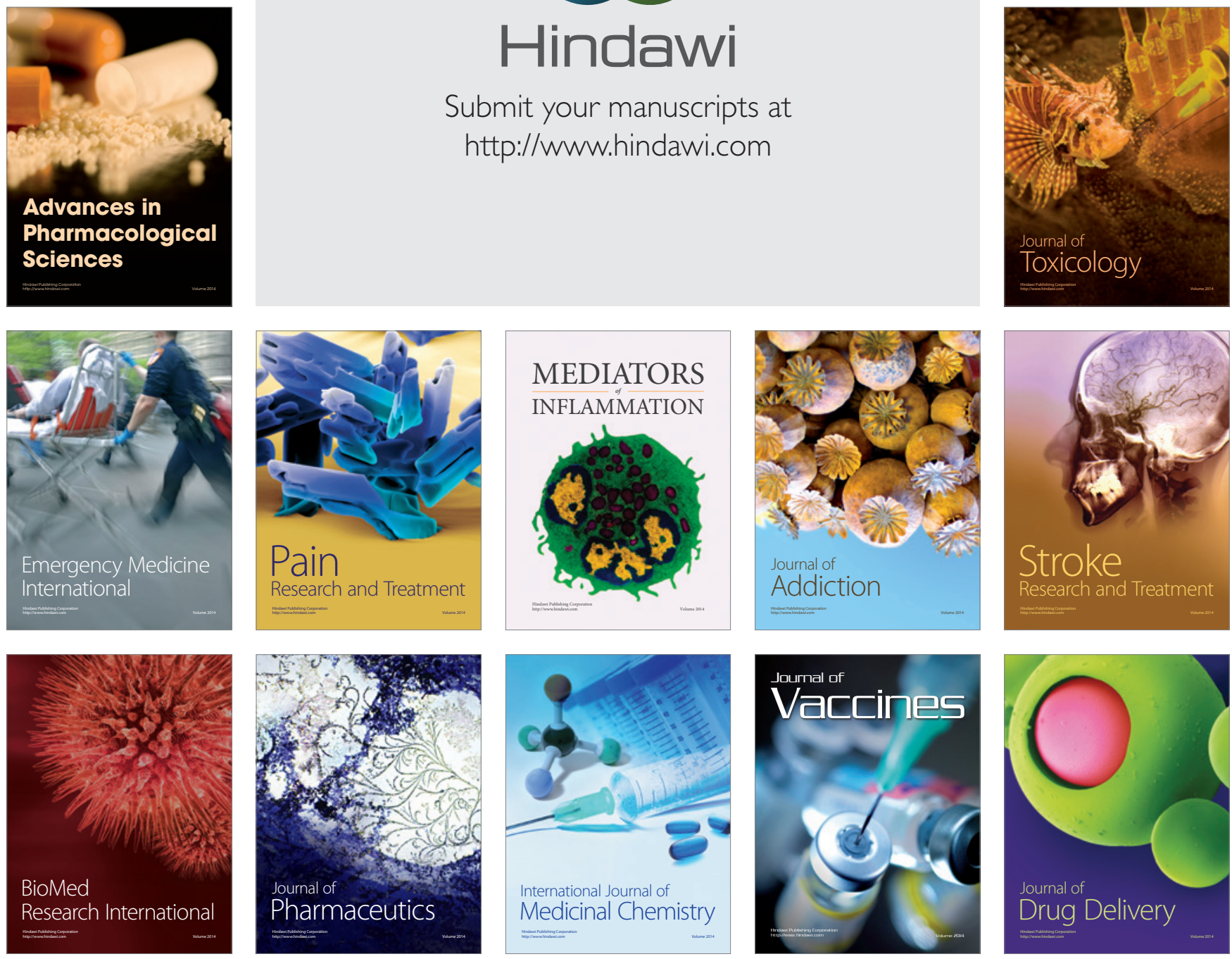